\title{
„A TUDOMÁNYT NEM LEHET ORSZÁGHATÁROK KÖZÉ ZÁRNI” Az EISZ által támogatott Kárpát-medencei magyar kutatóhelyek
}

A címben idézett mondat a Nemzeti Kutatási, Fejlesztési és Innovációs Hivatal elnökének, Birkner Zoltánnak abban a beköszöntőjében olvasható, amelyet az Elektronikus Információszolgáltatás Nemzeti Program (EISZ) által támogatott külhoni magyar intézményekről készült kötethez írt. A hivatal küldetése az aktív tudástranszfer ösztönzése és az innovációs ökoszisztéma kiépítése a teljes magyarság érdekeinek szolgálatában. A célok elérésének záloga a színvonalas kutatási infrastruktúra, a korszerü tudásbázisok, a magasan kvalifikált oktatók és kutatók, továbbá az ösztönző pályázati rendszer megléte - országhatárainkon belül és kívül egyaránt. Az EISZ-program támogatásával 2020-ban már második alkalommal kaptak hozzáférést a határon túli magyar kutatóhelyek a tudományos munkához és kutatáshoz nélkülözhetetlen magyar nyelvü e-könyves adatbázisokhoz.

A magyar intézményi hálózat kutatási és közmüvelődési feladatait támogató EISZ-program közel két évtizede müködik - tudjuk meg Lencsés Ákos írásából. Az EISZ a szakirodalmi adatbázisok konzorciumi szintű beszerzésével a kutatói közösség érdekeit szolgálja - többek között a kiadói tárgyalások és a közbeszerzési eljárások menedzselésével, illetve az adatbázisok előfizetési díjához nyújtott központi támogatással. A programhoz csatlakozott intézmények kutatói számára további előnyös helyzetet teremtenek az EISZ által egyes kiadókkal megkötött szerződések az open access publikálás lehetőségének biztosítására.

Az elektronikus információszolgáltatásra irányuló program nemcsak a bevezetőben említett magyar, de a nemzetközi adatbázisok elérését is biztosítja a Kárpát-medencében élő magyarság számára. A két évvel ezelőtt indult támogatási rendszernek köszönhetően az EISZ-program az ország határain kívül müködő magyar intézmények előfizetési díjait teljes egészében finanszírozza, magára vállalva az intézményi rendszerhasználati díjat és a nemzetközi adatbázisok előfizetési díjának önrészét.

Néhány jellemző adat a külföldön működő magyar intézményekről, illetve a támogatás révén általuk elérhető magyar nyelvű szakirodalmi forrásokról: 2020 első félévében 34 intézmény kapcsolódott be a programba, melynek keretében az érdeklődők több mint 8200 szakkönyvet tanulmányozhattak. Lencsés Ákos tájegységenként ismerteti az EISZ-ben részt vevő intézmények nevét és telephelyét, valamint az adatbázisok iránt legnagyobb érdeklődést mutató intézmények 2019. és 2020. évi használati adatait.

A határon túl élő magyarok kulturális hálózatáról, a hálózatot alkotó intézménytípusokról, illetve a könyvtárak, múzeumok, felsőoktatási és egyéb kulturá- 
lis intézmények, valamint civil szervezetek közötti formális kapcsolatokról szól Bali János tanulmánya. A szerző számba veszi a külhoni magyarság által lakott településeket: Kárpátalján 38, Erdélyben 379, Vajdaságban 115 olyan könyvtár müködik, amelyek állományában magyar nyelvü irodalom is helyet kapott. További együttműködési lehetőséget kínál a Magyar Vidéki Múzeumok Szövetsége, amely 2019-ben fogalmazta meg felhívását a határon túli múzeumok csatlakozására - rövid idő alatt 27 külhoni intézmény lépett be a szövetségbe. A felsoroltakon kívül az egyetemekkel szintén többrétü kapcsolatrendszer alakult ki az évek során, a kultúrházak körében viszont meglehetősen alacsony a formális hálózatosodás mértéke.

Az utóbbi évtized kormánypolitikája révén megerősödött a határon túli magyarság kulturális hálózata. A korábbi informális kapcsolatok talaján újabban formális kapcsolatok épültek ki az intézmények között. A felsőoktatásban jó példa a hálózatépítésre a négy magyarországi felsőoktatási intézménnyel kapcsolatban lévő Székelyudvarhelyi Egyetemi Központ (SZÉK), amelynek képzéseit a Magyar Akkreditációs Bizottság is akkreditálta. Kolozsváron müködik az egyetemi mühelyek mellett kutatási tevékenységet végző Max Weber Társadalomkutatásért Alapítvány, amelynek célja a tudomány-, oktatás- és kutatásszervezés, az ismeretterjesztés, továbbá a szakmai és gazdasági érdekképviselet.

Az Európai Unió 2014-2020-as pénzügyi ciklusa számos lehetőséget kínált a határokon átívelő kulturális hálózatépítés számára. Ezt felismerve több civil szervezet pályázott eredményesen az uniós forrásokra - köztük például a szlovákiai Nagykapos és Vidéke Társulás. Egyes kutatási mühelyek fontos szerepet játszanak a külhoni magyarság kulturális hálózatának kiépítésében. A román állam fenntartásában működő kolozsvári Nemzeti Kisebbségkutató Intézet fö feladata az erdélyi magyarsággal kapcsolatos társadalomtudományi kutatás. Jelentős kultúraszervező és kutatási munkát végez a szlovákiai Somorján a Fórum Kisebbségkutató Intézet és a szerbiai Zentán a Vajdasági Magyar Mủvelődési Intézet. A felsorolásból nem maradhatnak ki a Balassi Intézet által kiépített és működtetett külföldi magyar intézetek, amelyek hálózata jelenleg huszonkét országban huszonnégy intézettel képviseli a magyar kulturális diplomáciát szerte a világban.

A Magyar Tudományos Akadémia és a határon túli magyar tudományosság kapcsolata címü tanulmányában Morvai Tünde ismerteti a határon túli magyar kutatók és tudományos mühelyek támogatásának, illetve a hazai és a külhoni kutatók közötti kapcsolattartás formális rendszerét, valamint a külhoni kutatók tudományos munkásságának elismerésére létesített különböző díjakat.

Az ún. akadémiai törvény rendelkezik a Magyar Tudományos Akadémia (MTA) közfeladatairól - köztük a határon túli magyar tudományosság támogatásáról, illetve a külföldön élö, ott magyar nyelvủ és/vagy magyar témájú tudományos kutatást folytatókkal való kapcsolattartásról. Az MTA már a rendszerváltás 
utáni első évtizedben megteremtette e fontos feladat ellátásának pénzügyi és személyi alapjait. 1997-ben létrejött a Domus Ösztöndíjprogram a kutatási lehetőségek biztosítására, a Magyar Tudományosság Külföldön Elnöki Bizottság feladata pedig a Kárpátokon inneni és túli magyar tudós közösségek összefogása.

Az Akadémia köztestületébe 2000 óta jelentkezhetnek tagnak a határon túli magyar kutatók. A tanulmány közli néhány szomszédos ország külső köztestületi tagjainak létszámát: Románia 905 fővel, Szerbia 120 fővel, Szlovákia 100 fővel, Ukrajna 169 fővel képviselteti magát. Az MTA külső köztestületi tagjai, illetve a határon túli PhD-hallgatók részt vehetnek a Domus Ösztöndíjprogramban. A külhoni magyar tudósok munkájának elismerésére az MTA 2004-ben megalapította az Arany János-díjat, amelyet három kategóriában ítélnek oda: Életmüdíj, Kiemelkedő Tudományos Teljesítmény Díj, Fiatal Kutatói Díj.

A kötet egyik érdekes és értékes fejezete az EISZ-programba bekapcsolódott intézményeket mutatja be. Az ismertetőket földrajzi tájegységenként rendszerezték: a lapokon Dél-Baranya, Erdély és Partium, Felvidék, Kárpátalja, Muravidék, illetve a Vajdaság magyar egyetemeiről, könyvtárairól, múzeumairól, művelődési központjairól és további kulturális intézményeiről szóló tájékoztatók sorakoznak egymás után. A recenzió szükre szabott terjedelme nem teszi lehetővé, hogy a kötetben szereplő valamennyi intézményről szóljunk - viszont közülük néhányat kiemelni igazságtalan lenne. Az intézmények tevékenységének legfontosabb elemeit bemutató szöveg mellett számos kitünő minőségủ színes fotó látható a könyvben, amely jószerével akár útikönyvként is funkcionálhat.

A záró fejezet a SZAKTÁRS-adatbázisból azokat a szakkönyvkiadókat ismerteti, amelyek az EISZ-programon keresztül hozzáférést nyújtanak az online elérhető, szerzői jogi védelem alatt álló új könyveikhez a határon túli intézmények számára. A Magyar Tudományos Akadémia Könyvtár és Információs Központ kiadásában megjelent, kitünően szerkesztett, tartalmában és kivitelében egyaránt igényes kötetet öröm kézbe venni, de akinek erre nincs lehetősége, az online verzióját elolvashatja az MTA Könyvtárának repozitóriumában.

(Lencsés Ákos szerkesztö: Tudomány határok nélkül. Magyar kutatóhelyek a Kárpát-medencében. Budapest: Magyar Tudományos Akadémia Könyvtár és Információs Központ, 2020, DOI: 10.36820/tudomany.2020, http://real-eod.mtak. hu/9323/)

Tószegi Zsuzsanna

c. egyetemi docens Eötvös Loránd Tudományegyetem Bölcsészettudományi Kar Könyvtár- és Információtudományi Intézet 